\title{
Improving Mathayom 2/2 Student Learning Interest in Cell Materials Using Augmented Reality (AR) in Streesmutprakan School, Samut Prakan Province, Thailand
}

\author{
Amala Sholeha Apridza ${ }^{1)}$, Erlia Narulita ${ }^{2)}$, Anusorn Kongsawang ${ }^{3)}$ \\ ${ }^{1)}$ Student of Biology Education Study Program, Mathematics and Science Education Department, Faculty \\ of Teacher Training and Education, University of Jember \\ amalasholeha22@gmail.com \\ ${ }^{2)}$ Lecture of Biology Education Study Program, Mathematics and Science Education Department, Faculty \\ of Teacher Training and Education, University of Jember \\ Erlia.fkip@unej.ac.id \\ ${ }^{3)}$ Biology Teacher of Streesmutprakan School, Thailand
}

\begin{abstract}
This study aimed to describe the use of media Augmented Reality (AR) to improve learning interest in Matayom 2/2 class students who are lower secondary grades at Streesmutprakan School. This was a classroom action research (CAR) consisting of two cycles. Each cycle consists of planning stage, acting, observing and reflecting stage. The subjects of this study were all 34 students of Matayom 2/2 class. Data collection techniques included observation, interviews, and documentary analysis. Data analysis techniques used qualitative descriptive analysis. The results showed that students' learning interest in the first cycle was 3.3 with medium criteria, increasing to 4.4 with high criteria in the second cycle. The use of media Augmented Reality (AR) can increase students learning interest in Matayom 2/2 at Streesmutprakan School, Samut Prakan Province, Thailand.
\end{abstract}

Keywords: Augmented Reality, Cell Material, 3D Media, Learning Interest.

\section{INTRODUCTION}

Education is the most important thing in life. Education has an important role in all aspects of human life (Mulyasa, 2013). Education is naturally a human need. Without education, then in living this life humans will not be able to develop and will even be retarded. Thus, education must be truly directed to produce quality human beings who are able to compete (Triyanto et $a l, 2013)$. In practice, education is also closely related to learning. The main objective of education is learning.

In connection with the learning process, Fatkhurrohman (2009) said learning is a process of change in human personality and these changes are expressed in the form of increasing the quality and quantity of behavior such as increasing skills, knowledge of attitudes, habits, understanding, skills, thinking power and abilities other. Meanwhile, according to Slameto (2010), learning is a business process carried out by individuals to obtain a new behavior change as a whole, as a result of the individual's own experience in interaction with the environment. One of the drivers in learning success is student learning interest. Interest in learning is one of driving force to achieve learning goals.

Slameto (2010) said that developing an interest in learning is basically helping students to see how the relationship between material that is expected to be learned by themselves as individuals. This process means showing students how certain knowledge or skills affect themselves, serving their goals, satisfying their needs. When students realize that learning is a tool to achieve several goals that are considered important, and if students see that the results of their learning experience will bring progress to themselves, most likely they will be interested and motivated to learn them. Student learning interest does not appear by itself but there are factors that can influence the emergence of learning interest, one of which is learning media. 
Based on the observations in the Matayom 2/2 class, there was still a low interest in learning. This can be seen from the lack of student attention, student participation, and student order during learning, especially in the material about cells. Students are still seen talking with friends when the teacher explains and does not even participate in learning. According to the informant, the teacher in the class mentioned that students sometimes did not focus their attention on the teacher. The teacher only uses the lecture method and the textbook media as material for learning. This is felt to be insufficient to attract students 'attention, so a solution is needed so that students' interest in learning increases.

In connection with that particular matter, it is needed to increase students' learning interest in Matayom 2/2 class, namely by using Augmented Reality (AR). Learning media becomes important in increasing student learning interest. According to Miarso (2000), media is everything that can be used to stimulate students' thoughts, feelings, and willingness so that they can encourage the learning process in students. In addition, the media is a physical form of educational technology which includes words or sentences, films, tapes, slides, videos and so on. One of the current media that is very interesting to use is Augmented Reality (AR) which is a technology in the multimedia field that can combine one or more 3D objects into the real environment using camera media. The advantage of Augmented Reality is that it can display interesting visualizations as if 3D objects are in a real environment.

Based on the background above, the researcher made observations to find out whether students' interest in learning could increase with the use of Augmented Reality (AR) on material about cells. Augmented Reality (AR) is expected to be an alternative learning media for the introduction of cell material so that it can increase students' interest in one of the materials in the biology lesson.
Streesamutprakan School, especially in the lower secondary school or equivalent to Junior High School located at 489 Moo 1, Sukhumvit Road, Pak Nam Sub-District, Mueang Samut Prakan 10270, Samut Prakan, Thailand.

This study involved respondents from Matayom 2/2 students with a total of 14 male students and 20 female students, bringing the total to 34 respondents.

Data collection techniques in this study used observation, interviews, and documentation. Data analysis method used qualitative descriptive analysis. This class action research procedure each cycle consisted of four activities, namely: 1) Planning, before conducting research researchers formulate the problem formulation, objectives and make action plans, including research instruments and learning tools. 2) Actions and observations or observations, including actions taken by researchers as an effort to build students' conceptual understanding and observe the results or impact of using Augmented Reality (AR) media. 3) Reflection, the reflection phase is needed to examine a series of activities that have been done before. Reassessment can be used by researchers to find out the activities that have been achieved and that have not been achieved during the implementation of actions and observations. 4) Improvement plan, Activities carried out at the planning stage in cycle II, based on reflections from cycle I, obtained data on deficiencies that occurred in cycle I which was a reference for implementing corrective actions in cycle II so that the results of the actions achieved were more optimal.

Retrieval of data by means of observation using 4 indicators that show students' interest in learning with the following categories:

\section{$\geq 2.1$ - $\leq 3$ Low student learning interest \\ $\geq 3.1-\leq 4$ Moderate student learning interests \\ $\geq 4.1-\leq 5$ High student learning interest}

\section{RESEARCH METHODS}

This research was a classroom action research (CAR) conducted at 


\section{RESULT AND DISCUSSION} Result

This research consisted of two cycles, each cycle consisting of one meeting. In the first cycle, the teacher has not used Augmented Reality (AR) media but students have used a textbook that can support the use of AR applications.

Constraints faced in cycle I can be improved in cycle II, so that in cycle II learning using Augmented Reality media runs smoothly and according to the plans that have been made in the RPP. The score of students 'learning interest in the first cycle is seen in table 2 and the score of students' learning interest in cycle II is shown in table 3 below:

Table 2. The Average Matayom Student Learning Interest 2/2 Years of School Preparation in Cycle I

\begin{tabular}{|c|c|c|c|}
\hline No. & $\begin{array}{c}\text { Indicators of } \\
\text { Student } \\
\text { Learning } \\
\text { Interests } \\
\end{array}$ & $\begin{array}{l}\text { Cycle } \\
\text { I }\end{array}$ & Criteria \\
\hline 1 & $\begin{array}{l}\text { Students' } \\
\text { liking towards } \\
\text { lessons }\end{array}$ & 4.2 & High \\
\hline 2 & $\begin{array}{l}\text { Student } \\
\text { participation in } \\
\text { the learning } \\
\text { process }\end{array}$ & 2.9 & Low \\
\hline 3 & $\begin{array}{l}\text { The attention } \\
\text { of students } \\
\text { during the } \\
\text { teaching and } \\
\text { learning } \\
\text { process }\end{array}$ & 3.2 & $\begin{array}{c}\text { Moderat } \\
\mathrm{e}\end{array}$ \\
\hline \multirow[t]{2}{*}{4} & $\begin{array}{l}\text { Student } \\
\text { learning } \\
\text { persistence }\end{array}$ & 2.8 & Low \\
\hline & $\begin{array}{l}\text { Total Score - } \\
\text { rata }\end{array}$ & 3.3 & $\begin{array}{c}\text { Moderat } \\
\mathrm{e}\end{array}$ \\
\hline
\end{tabular}

Table 3. average Interest Student Matayom 2/2 Streesamutprakan School in Cycle II

\begin{tabular}{|c|c|c|c|}
\hline No & $\begin{array}{c}\text { The indicator of } \\
\text { Student Learning } \\
\text { Interest }\end{array}$ & $\begin{array}{c}\text { Cycle } \\
\text { II }\end{array}$ & Criteria \\
\hline 1 & $\begin{array}{l}\text { Student's liking } \\
\text { towards a lesson }\end{array}$ & 4.4 & High \\
\hline
\end{tabular}

\begin{tabular}{|c|l|c|c|}
\hline 2 & $\begin{array}{l}\text { Student } \\
\text { participation in } \\
\text { the learning } \\
\text { process Mega }\end{array}$ & 4.9 & High \\
\hline 3 & $\begin{array}{l}\text { The attention of } \\
\text { students during } \\
\text { the teaching and } \\
\text { learning process }\end{array}$ & 4.2 & High \\
\hline 4 & $\begin{array}{l}\text { Student learning } \\
\text { persistence }\end{array}$ & 4.2 & High \\
\hline & Total Score-rata & 4.4 & High \\
\hline
\end{tabular}

Table 2 above shows that the average score of student interest has increased. In the first cycle the average score of students' learning interest was 3.3 with the medium criteria and then in Table 3 , it was seen that the cycle II increased to 4.4 with high criteria. Indicators Sense of learning and attention of students during the teaching and learning process both in the first cycle and second cycle are at high criteria. Increasing students 'interest in learning above, can be seen in the following diagram:

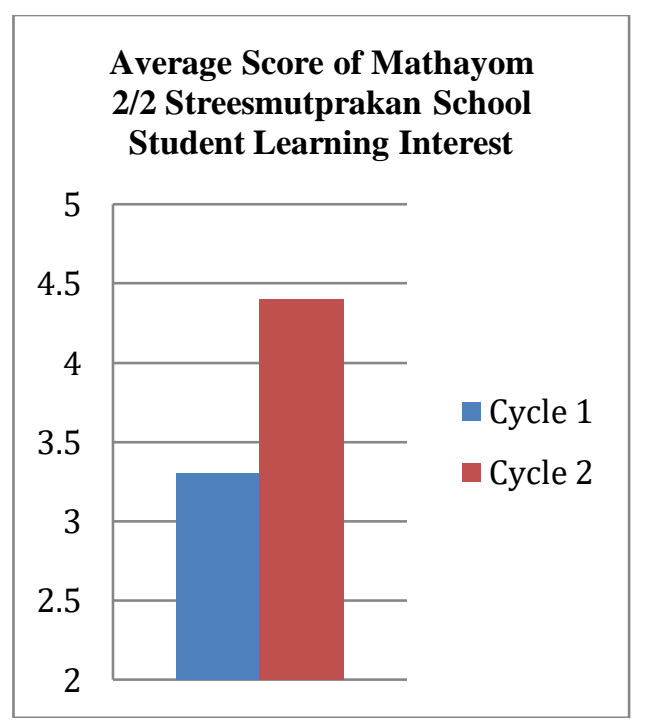

Figure 1. Diagram of increasing student learning interest Cycle I and Cycle II

The picture above shows that there is an increase in the average score of students' interests in learning from cycle I to cycle II. Increasing the average score of interest in learning in cycle II shows a score of 3.2 with high criteria. This is shown by the sense of liking students pay attention to the teacher's explanation and the attention of the students 
while following the learning with Augmented Reality (AR) media well.

\section{Discussion}

Research results show that the use of Augmented Reality (AR) media can increase students' interest in learning biology material about Matayom 2/2 Streesamutprakan School student cells, Samut-Prakan, Thailand 2018/2019 school year. Student learning interest increases from the medium to high category. In cycle I, students have used textbooks that support AR applications, but still have not used this application as a media because many students cannot download AR applications because the size of the application is very large around $167 \mathrm{MB}$, so this is one of the obstacles in the use of AR, in addition to the teacher's concern if using AR media, students are more afraid of focusing on other applications on their cell phones than learning to use this application.

In the second cycle, there was an increase in students' interest in learning, this was supported by the completion of the constraints in cycle I. In order for students to maximize the AR media, several groups were made and in each group there was one student cell phone that had an AR application so that a group was formed. This is quite effective because not all students have to download an application that has a very large size and also this maximizes learning because students focus on 3D media on one cell phone in each group. With this, teachers 'concerns can be overcome because the focus of students' attention will not be shared with other applications on their respective cellular phones.

Increasing students' interest in learning can be seen in the learning process using Augmented Reality (AR) learning media, students take advantage of the time given by the teacher, which is proven by the students can understand the material explained by the teacher using Augmented Reality (AR) media. Students are seen paying attention to the media and students' liking towards the lesson is also seen by the response of students, and students understand the lesson better. Student interest also appeared in asking and answering activities. This showed that students' interest in learning increases with participation.

Increased interest in student learning is also recognized by the Matayom $2 / 2$ biology teacher as the implementer of learning improvement activities, based on the results of interviews with teachers, stated:

"I am very happy, students can have increased learning interest as it is currently primarily about cell matter. I only use this textbook as a supporting media when explaining and rarely using the Augmented Reality (AR) feature, but with the division of groups and there are only one media in each group, this is effective enough to attract attention and students focus on ongoing learning " (Teacher Tam, 28 years).

Based on the teacher's statement above the Augmented Reality (AR) media facilitates the teacher in learning. This is in line with what was conveyed by (Ali, 2010) which states that the media has a very important role because it can directly visualize the form, process, or structure of an object. The media is also an intermediary of teachers with students so that students are able to capture and receive messages from the learning provided by the teacher. The selection of media must be adjusted to the learning objectives and the nature of the material that is the main subject of learning. Learning media means everything that can be used to channel messages (messages), stimulate the mind, feelings, attention, and willingness of students so that it can encourage the teaching and learning process.

According to Sudjana and Ibrahim (2009) explains that teaching will be more effective if objects and events that become teaching material can be visualized realistically or resemble the actual circumstances, but that does not mean that the media must always resemble the actual situation. This understanding strongly supports the benefits of Augmented Reality (AR) media.

According to Martono (2011), the use of Augmented Reality (AR) technology will be very helpful in conveying information to users, in this case, the students. Augmented reality is an interactive 
technology that combines the real world and virtual world. According to Ronald Azuma (1997), there are three principles of augmented reality, namely (1) augmented reality is a combination of real and virtual worlds, (2) run interactively in real time, and (3) there is integration between objects in three dimensions, namely virtual objects integrated in the real world. With the characteristics possessed by the AR media, it can be very helpful in learning specifically about cell matter because cells are the smallest unit structures that are generally microscopic or cannot be seen with the naked eye.

Student interest in Augmented Reality (AR) media can also be seen from interviews conducted with students in the class, one of which is as follows:

"I am very happy to learn to use Augmented Reality (AR) media, with the use of this media in groups also makes it easier for us to understand material about cells and allows us to discuss with friends in our group. In addition, the textbooks that we have can be used optimally by utilizing Augmented Reality (AR) media and not only reading ordinary textbooks" (Student L, 13 Years).

Fatmawati (2018) states that the material regarding animal cells and plant cells is abstract enough to be understood by students. From the observations he made during the course, the students seemed confused with the material. They say that students only know the general material contained in the book, but do not know in detail both the shape and function of animal and plant cell organelles. So that with the cell material characteristics that are so abstract, the media in the form of Augmented Reality (AR) will greatly help students to increase learning interest, especially regarding cell material.

Based on the results of this class action research proves that the results of this study have answered the action hypothesis that is the use of Augmented Reality (AR) Mulyasa. 2013. Development and implementation of the 2013 curriculum. Bandung: PT. Teen Rosdakarya. learning media can increase students' interest in learning Matayom 2/2 Streesamutprakan School 2017/2018 school year.

\section{CLOSING}

Based on the results of research and discussion, it can be concluded that the use of Augmented Reality (AR) media can increase students' learning interest in the material about cells in Matayom 2/2 Streesamutprakan School in 2018/2019. Increasing students' interest in learning can be seen from the average score of interest before action, which is 3.3 with the medium criteria in the first cycle and has increased to 4.4 with high criteria in the second cycle. This shows the achievement of the objective of research on the use of Augmented Reality (AR) media.

\section{REFERENCES}

Ali, Muhammad. 2010. Teacher in the Teaching and Learning Process. Bandung: Sinar Baru Algesindo.

Azuma, Ronald T. 1997. A Survey of Augmented Reality, In Presence: Teleoperators and Virtual Environments 6: 355-385.

Fatkhurrohman, Pupuh. 2009. Teaching and Learning Strategies Through Planting General Concepts. Bandung: Refika Aditama.

Fatmawati, B. 2018. Student Creativity in Creating Cell Organelles as Media for Learning. International Conference on Science Education (ICoSEd). (1006): 1-8.

Martono, Kurniawan Teguh, and Kurindalukmana, Rinta. 2014. Mobile Augmented Reality of the Android-based Diponegoro University Computer Systems Department (MARSISKOM). Volume 4 (1): 1-8.

Miarso. 2000. Various Learning Media. Jakarta: PT Raja Grafindo.

Slameto. 2010. Learning and Influencing Factors. Jakarta: Rineka Cipta.

Sudjana, Nana and Ibrahim. 2009. Educational Research and

Bioedukasi Vol. XVI. No. 2 Oktober 2018 
Assessment. Bandung: Sinar Baru Algesindo.

Triyanto, Eko., Sri Anitah, and Nunuk Suryani. 2013. The Role of Principal Leadership in Utilizing Learning Media as an Effort to Improve the Quality of the Learning Process. Educational Technology Journal. Volume 1 (2): 226-238. 